\title{
ВОПРОСЫ ОЗДОРОВЛЕНИЯ БАНКОВСКОГО СЕКТОРА КАЗАХСТАНА
}

\author{
Н. А. Гумар, ассоциированный профессор, кандидат экономических наук, \\ Г. К. Жанибекова, ассоичированный профессор, $P h D$, \\ Каспийский общественный университет. \\ 2. Алматы., Казахстан
}

DOI: https://doi.org/10.31435/rsglobal_ijite/31032019/6375

\section{ARTICLE INFO}

Received 13 January 2019

Accepted 25 March 2019

Published 31 March 2019

\section{KEYWORDS}

asset quality, loan portfolio,

European Union, SLB,

concentration of banks,

refurbishment,

capital restructuring.

ABSTRACT

Monetary policy is affected by a slowdown in economic growth. In the formation of financial stability cannot do without measures to improve the banking sector.

Obviously, the accumulation of risks in this area is fraught with the inability of the banking sector to show resilience to external shocks.

The banking sector rehabilitation program in Kazakhstan is a wide range of activities, including the assessment of the quality of banks 'assets, so-called stress testing, and support for SLBs from the resources of the National Bank, provided that they are capitalized by second-level banks' shareholders.

The main directions of the Program are: increasing the financial stability of the system-forming bank; Increasing financial stability of large STBs and change the regulatory and supervisory environment to improve the financial stability of the banking sector.
\end{abstract}

Citation: N. A. Gumar, G. K. Zhanibekova. (2019) The Issues of Improvement of the Banking Sector of Kazakhstan. International Journal of Innovative Technologies in Economy. 2(22). doi: 10.31435/rsglobal_ijite/31032019/6375

Copyright: (C) 2019 N. A. Gumar, G. K. Zhanibekova. This is an open-access article distributed under the terms of the Creative Commons Attribution License (CC BY). The use, distribution or reproduction in other forums is permitted, provided the original author(s) or licensor are credited and that the original publication in this journal is cited, in accordance with accepted academic practice. No use, distribution or reproduction is permitted which does not comply with these terms.

Введение. В банковской системе Евразийского союза в настоящее время банковский сектор Казахстана является самым слабым звеном.

В 2017 г. в Послании «Третья модернизация Казахстана: глобальная конкурентоспособность», Нурсултан Назарбаев поручил Национальному банку выработать комплекс мер по оздоровлению банковского сектора. Президент сказал, что надо ускорить расчистку балансов от «плохих кредитов».

Значительное присутствие в ссудном портфеле банков неработающих заимов снижает качество активов. Качество портфелей банков является ключевым показателем, от уровня которого зависит состояние финансового рынка страны и его участников. Ухудшение макроэкономических факторов воздействует на финансовое положение и платежеспособность замщиков банка. Прекращение платежей и невозврат кредитов ведет к возрастанию неработающих займов.

Методы. В процессе исследования использовались различные нормативные, методические, инструктивные положения по банковскому делу, материалы различных научнопрактических конференции. В ходе исследования использованы материалы периодической печати и официальных веб-сайтов, а также научные результаты автора, выявленные в процессе подготовки данной научной работы. Для решения поставленных задач в работе использованы различные методы и приемы, в частности: методы экономического, абстрактно-логического, экспертного сравнения.

Результаты и обсуждение. В настоящее время проблемы развития и совершенствования системы управления кредитным портфелем в целях минимизации его 
рисков приобрели особую актуальность и значимость. Современный кредитный портфель выступает определенным критерием, позволяющим судить о качестве кредитной политики банка и о конкурентоспособности банка, способности противостоять воздействию внешних и внутренних факторов деятельности.

Возникновение у банков некачественных активов связано с предоставлением кредитов несостоятельным заемщикам, которым займы были выданы под некачественные залоги: под деньги и имущество поступающим в будущем, страховые полисы аффилированных компаний, под гарантии физических лиц, невозвратное кредитование бизнеса акционеров банка. Кредитные учреждения по некоторым займам стараются провести их реструктуризацию и перенести время возврата на более позднеее сроки. Однако эти меры не решают проблемы наличия неработающих кредитов.

Эффективность управления ссудным портфелем банка зависит от грамотной организации процесса кредитования, где одновременно и системно учтены все воздействующие на данный процесс факторы, которые сочетаются с законами кредита, его методами и принципами в рамках современной научной концепции риск менеджмента банка.

По данным Национального банка РК объем неработающих займов в настоящее время составляет более $7,4 \%$. Учитывая низкое качество финансового положения многих заемщиков можно предположить, что потенциальный объем неработающих кредитов значительно выше представленного показателя. Поэтому состояние качества активов банков второго уровня требует проведения мер объективной их оценки с привлечением независимых экспертов [1].

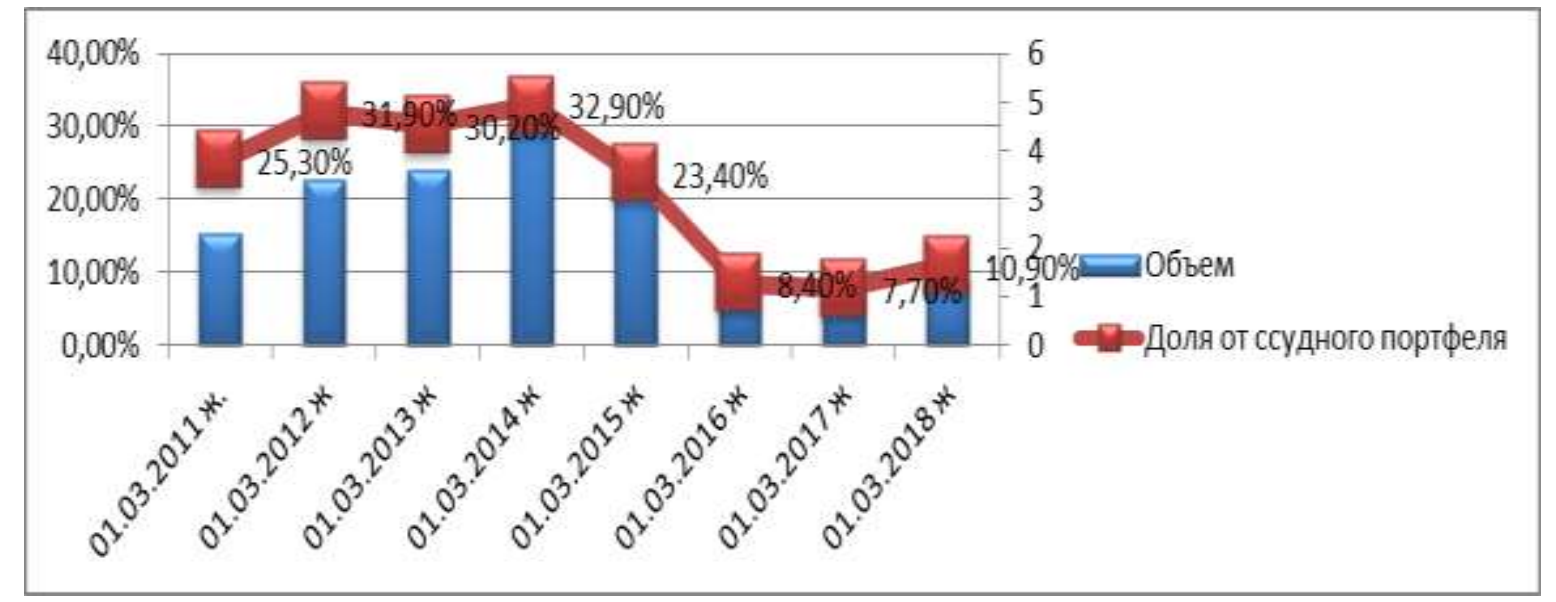

Рис. 1. Кредиты с просрочкой платежей свыше 90 дней (март 2018 г.)

На 1 июля 2017 года кредиты, по которым имеется просроченная задолженность более 90 дней (NPL), составили 1 663,0 млрд. тенге или 10,7\% от ссудного портфеля. Провизии по ссудному портфелю сформированы в размере 1734,4 млрд. тенге или $11,2 \%$ от ссудного портфеля (на начало 2017 года - 1642,9 млрд. тенге или 10,6\%), рис.1.

Кредитный рынок, после заметного сокращения в 2017 году, в 2018 году фактически стагнирует. Ссудный портфель банков второго уровня к сентябрю 2018 года составляет 13,6 триллион тенге - на 1,2\% меньше, чем годом ранее, и сразу на $13,2 \%$ меньше, чем в аналогичном периоде 2016 года.

Качество займов заметно улучшилось: кредиты с просрочкой платежей составили по итогам 3 квартала 2018 г. лишь 13,1\% от портфеля, опасные наиболее токсичные займы с просрочкой свыше 90 дней - всего 8,2\%. Для сравнения, 2017 г. показатели составляли 18,8\% и $12,8 \%$, соответственно.

Можно сказать, что продолжается снижение роли банковской системы в развитии экономики Казахстана, как видно доля ссудного портфеля банковского сектора к ВВП последовательно снижаясь за 2018 год составляет $23 \%$ (с $26 \%$ в 2017 г. и с $33 \%$ в 2016 г). Результаты оценки позволяет вплотную подойти к выявлению количества состоятельных и численности несостоятельных банков. К жизнеспособным банкам можно применить инструменты рекапитализации и реструктуризации, к нежизнеспособным - запустить механизм 
санации. Состоятельный банк должен провести работы по расчистке баланса от сомнительных и невозвратных кредитов. После этого необходимо обязать акционеров банка осуществить его докапитализацию, что позволит повысить устойчивость банка [2].

Правовые и экономические условия оздоровления проблемных банков должны обеспечить проведения этих мероприятий без подрыва доверия к банковскому сектору. Эффективные меры по отношению к недостаточно устойчивым банкам позволяют значительно сократить издержки по достижению финансовой стабильности. Раннее выявление проблемы потребует меньше социальных и экономических затрат на ее преодоление. На финансовом рынке должны функционировать только эффективные и финансово устойчивые банки, которые могут осуществлять свою деятельность без подрыва стабильности банковской системы.

В условиях изменчивости в стране и мире, а также вызовов, стоящих перед банками, и желании их остаться на рынке банковских услуг требует от банков принятия соответствующих мер или объединения или докапитализации. Инициативы банков по этим вопросам, обеспечивающих стабильность всей банковской системы, соответсвует международной практике и получил положительную оценку МВФ.

Стремление отдельных банков к объединению и увеличению капитализации будет способствовать улучшению бизнеса - процессов по обслуживанию клиентов. Монетарные власти готовы оказать необходимую поддержку банкам по скорейшему завершению процесса объединения, так как они направлены на повышения эффективности банковского бизнеса.

Оздоровление банковского сектора путем реализации международных принципов регуляторного и надзорного процесса предусматривает усиление работ по предупреждению возникновения проблем и рисков. Внедрение риск - ориентированного надзора, принятого в Евросоюзе, предполагает использования превентивных мер в отношении банков, ведущих рискованную деятельность. Оценка жизнеспособности банка, систем управления рисками, внутреннего порядка определения достаточности капитала и ликвидности позволяет принять меры раннего реагирования, которые должны стать основой для применения санации и принудительных мер. Данные подходы дадут возможность поэтапно снижать степень подверженности банков различным рискам. Ужесточение условий сделок банков с аффелированными лицами и ограничения совершения сделок на льготных условиях должно способствовать улучшению всех этих мер на законодательном уровне обеспечит проведения принудительной реструктуризации капитала и должны стать основой для упрощения процесса объединения банков [3].

В настоящее время на денежно-кредитном рынке Казахстана начался активизироваться процесс концентрациии банков. Из действующих 33 банков 6 банков заявили о возможности слияния.

АО «Халык банк» реализует потенциальную сделку по вхождению в капитал Казкоммерцбанка. Докапитализация Казкома до достаточного уровня должно обеспечить его бесперебойную работу. Базовым условием вхождения Халык банка в капитал Казкома является соблюдения прав и законных интересов депозиторов, кредиторов и контрагентов по договорам.

Однако для реализации сделки по покупке АО «Халык банком» акции АО «Казкоммерцбанка» необходимо проведение совместной независимой проверки качества активов Казкома. Известно, что более $50 \%$ кредитного портфеля АО «Казкоммерцбанка» являются объязательствами Банка Туран Алем. Активы последнего относятся к активам долгосрочного заимствования, то есть с длительным процессом восстановления стоимости. Эти активы не формируют достаточный уровень финансовых потоков для содержания Казкома.

С целью обеспечения финансовой устойчивости Казкоммерцбанка следует отделить активы БТА банка от активов Казкома. В рамках возможной сделки между двумя банками предусматривается передача активов АО «Казкоммерцбанка» в Фонд проблемных кредитов. ФПК в дальнейшем обеспечить вовлечения данных активов в экономический оборот согласно проектов государственно-частного партнерства [4].

В этом финансовом институте будет сосредоточено более треть активов всего банковского сектора Казахстана, что сделает финансовый институт крупнейшим банком РК. Казкоммерцбанк и Халык банк по объему активов занимают первое и второе место соответственно. На начало марта 2017 г. портфель активов Казкома составил 4,7 трлн.тенге, Халык банка - 4,6 трлн.тенге. После их объединения в июне 2018 г. общий потенциальный 
размер активов был достигнуть до 5,1 трлн. тенге, что сделал его практически недосягаемым для других банков Казахстана. Доля данного банка за июнь 2018 г. в совокупном активе банков второго уровня выросла с 20,5\% до 20,8\%, доля ссудного портфеля - $16,3 \%$, вкладов - 38,3\% (рост сразу на 1,6 трлн тг, до 3,2 трлн тг (за счёт присоединения Казкоммерцбанка)) [1].

В феврале 2017 г. Цеснабанк и Банк Центр-Кредит (БЦК), по сведению совместного пресс-релиз, договорились о возможном слиянии. Нацбанк РК дал согласие Цеснабанку купить долю активов БЦК. Объединение как единого банка позволит упрочить свое положение на финансовом рынке.

Объявлено об объединении сделали Capital Банк и Tengri Банк, которые в середине марта 2017 г. подписали меморандум о намерении слияния в единый финансовый институт.

Напомним, в Послании народу Казахстана Президент отметил «Национальному банку нужно дать больше прав для оперативного контроля за состоянием банков. Он должен перейти от формализованного подхода к риск-ориентированному, чтобы принимать меры воздействия к банкам, не дожидаясь формального нарушения с их стороны», - и подчеркнул, что Нацбанк должен отвечать не только за инфляцию, но и совместно с Правительством за рост экономики.

Для спасения банков НБ РК в 2017 г. разработал программу оздоровления с общей суммой спасения в почти 3 трлн тенге. Из них 500 млн тенге будут направлены банкам с капиталом свыше 45 млрд тенге, которым требуется помощь. Нацбанк призывает акционеров участвовать в программе на справедливых условиях. Оздоровление банковского сектора способствует оживлению кредитования после нескольких лет стагнации.

Заключение. Резюмируя, надо констатировать, что проблема оздоровления банковского сектора Казахстана не является обособленной, лежащей в стороне от других экономических проблем. Она теснейшим образом связана с проблемами финансов, ценообразования и т.д., т.е. со всеми проблемами хозяйственного механизма. Следовательно, решение проблемы должно осуществляться одновременно с решением других экономических проблем [5].

Для решения проблемы оздоровления банковского сектора Казахстана и для недопущения повторения ситуации с высокорисковой политикой банков, а также в рамках усиления регуляторного и надзорного мандата, с 1 января 2019 года Национальный Банк вводит риск-ориентированный подход в надзорном процессе. Акционер фининститута как Национальный банк, должен поддержать банк капиталом.

\section{ЛИТЕРАТУРЫ}

1. Официальный сайт Национального банка РК - www.nationalbank.kz

2. Официальный сайт - www.Ranking.kz

3. Blanc, F., Macrae, D. and Ottimofiore, G. (2015), Understanding and addressing the Risk Regulation Reflex: Lessons from international experience in dealing with risk, responsibility and regulation, Prepared for the Dutch Risk and Responsibility Programm// available at www.government.nl

4. Гумар Н. А., Сейсенбаева А.М. Об эффективности системы кредитования предпринимательства. International Journal of Innovative Technologies in Economy. 5(17), Vol.1, June 2018

5. Проблемные активы БТА Банка отделят от Казкома// Информация с сайта: http:// https://informburo.kz/novosti/problemnye-aktivy-bta-banka-otdelyat-ot-kazkoma.html 